\title{
Comparison of Hind-Cast Wave with Measured Wave Off Puducherry Coast, Eastcoast of India
}

\author{
P. Mohamed Rajab' ${ }^{1 *}$, R. Mahadevan ${ }^{2}$ and P. Chandramohan ${ }^{3}$ \\ 'Department of Harbor \& Ocean Engineering, AMET University, 135, ECR, Kanathur, Chennai-603112, India; \\ mohamedrajab.p@ametuniv.ac.in \\ 2Department of Ocean Engineering, Indian Institute of Technology-Madras, Chennai-600 025, India; \\ mahadevanchandran@gmail.com \\ 3Indomer Coastal Hydraulics (P) Limited. Chennai - 600 087, India; ponpcm@gmail.com
}

\begin{abstract}
In the present study, the available hind-cast wave data off Puducherry coast in deep water are transformed to $15 \mathrm{~m}$ water depth using linear wave theory and compared with the wave data measured by Indian National Centre for Ocean Information Services (INCOIS), Hyderabad, in $15 \mathrm{~m}$ water depth off Puducherry coast. The correlation analysis, comparison of annual wave rose plot and scatter analysis are carried out for both the wave data at $15 \mathrm{~m}$ water depth. Based on correlation analysis, it can be seen that wave height and wave direction, the cross-covariance are high for both wave data. But for wave period, cross-covariance coefficient is significantly low. From the wave rose plot, it can be seen that incase of hind-cast data, predominantly waves coming from northeast direction $\left(60^{\circ} \mathrm{N}\right.$ to $\left.150^{\circ} \mathrm{N}\right)$ with the maximum wave height in the range of 0.5 to $2.0 \mathrm{~m}$. Where as measured data, predominantly waves coming from southeast direction $\left(90^{\circ} \mathrm{N}\right.$ to $\left.150^{\circ} \mathrm{N}\right)$ with maximum wave height in the range of 0.5 to $1.5 \mathrm{~m}$. From the scatter analysis of both the wave data, it is observed that the incase of hind-cast wave, $33 \%$ of the time wave approaching angle is less than $90^{\circ} \mathrm{N}$ where as measured wave it is $12 \%$ of the time. In case of hind-cast wave data, the number of event with wave height more than $1 \mathrm{~m}$ is around 976 (33.4\%) whereas in case of measured wave, it is around $500(17 \%)$ i.e. nearly half. The changes in the basic data on wave height, wave period and wave direction which will significantly influence in the estimation of littoral drift along the coast. It is however suggested to use the measured wave data for the estimation of sediment transport in order to arrive at more dependable values on littoral drift.
\end{abstract}

Keywords: East Coast of India, Hind-Cast Wave, Littoral Drift, Measured Wave, Puducherry

\section{Introduction}

The planning of any developmental activity in near shore regions, details of wave characteristics become a necessary pre-requisite. But wave measurement program is expensive and instrument recorded wave data are available only at a few places along the Indian coast. For initial estimates of site-specific design parameters and operational conditions, the readily available hind-cast wave data serves as an alternative source. But before using hind-cast wave data for field applications, it becomes necessary to analyze how the hind-cast data compared with measured data.

In the present study, the hind-cast wave data off Puducherry coast in deep water obtained from "Global Reanalysis of Ocean Waves" (GROW) data base for the period of one year i.e. from January 2008 to December 2008 were compared with the wave data measured for the same period by Indian National Centre for Ocean Information Services (INCOIS), Hyderabad, in shallower depth of $15 \mathrm{~m}$ off Puducherry coast.

${ }^{*}$ Author for correspondence 


\section{Materials and Methods}

\subsection{Measured Wave at $15 \mathrm{~m}$ Water Depth}

The available measured wave characteristics for the period of one year i.e. from January 2008 to December 2008 at $15 \mathrm{~m}$ water depth have been presented in the form of annual wave rose diagram (Figure 1). At $15 \mathrm{~m}$ water depth, wave height significantly varied between $0.2 \mathrm{~m}$ and $3.56 \mathrm{~m}$, the peak wave periods were between $2.5 \mathrm{sec}$ and $19.1 \mathrm{sec}$ and the wave directions were between $36.6^{\circ}$ and $179.1^{\circ}$ w.r.t. North.

The monthly variation of measured wave is presented in Table 1. The average significant wave heights vary from $0.56 \mathrm{~m}$ to $0.65 \mathrm{~m}$ from February to April, June and August and vary from $0.76 \mathrm{~m}$ to $0.88 \mathrm{~m}$ in May, July and from to September to November and January, and vary around 1.14 in December. The zero crossing wave periods vary from $3.5 \mathrm{~s}$ to $9.9 \mathrm{~s}$ over the whole year. The predominant wave direction prevails around $115^{\circ}$ during March and October, $120^{\circ}$ to $150^{\circ}$ in April to September, and $95^{\circ}$ to $100^{\circ}$ w.r.t. North from November to February.

\subsection{Hind-Cast Wave Data in Deepwater}

The hind-cast wave climate for the study region was compiled from the Global Re-analysis of Ocean Waves (GROW) data base ${ }^{3}$. The GROW data set contains the wave climate at 3 hourly intervals over spatial grids of $0.625^{\circ}$ along latitude and $1.25^{\circ}$ along longitude. The predicted (reanalyzed) wave data for a period of ten year

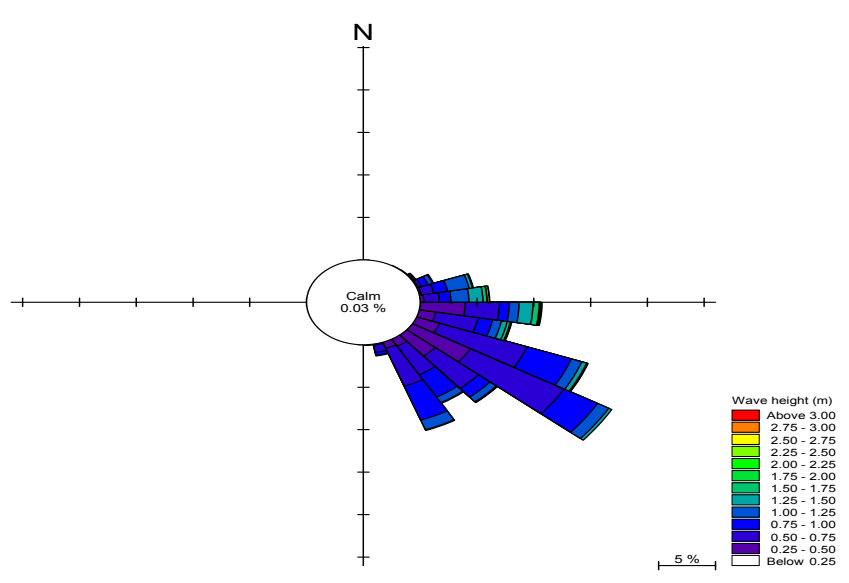

Figure 1. Annual rose diagram for measured waves at $15 \mathrm{~m}$ water depth.
Table 1. Monthly measured wave characteristics off Puducherry

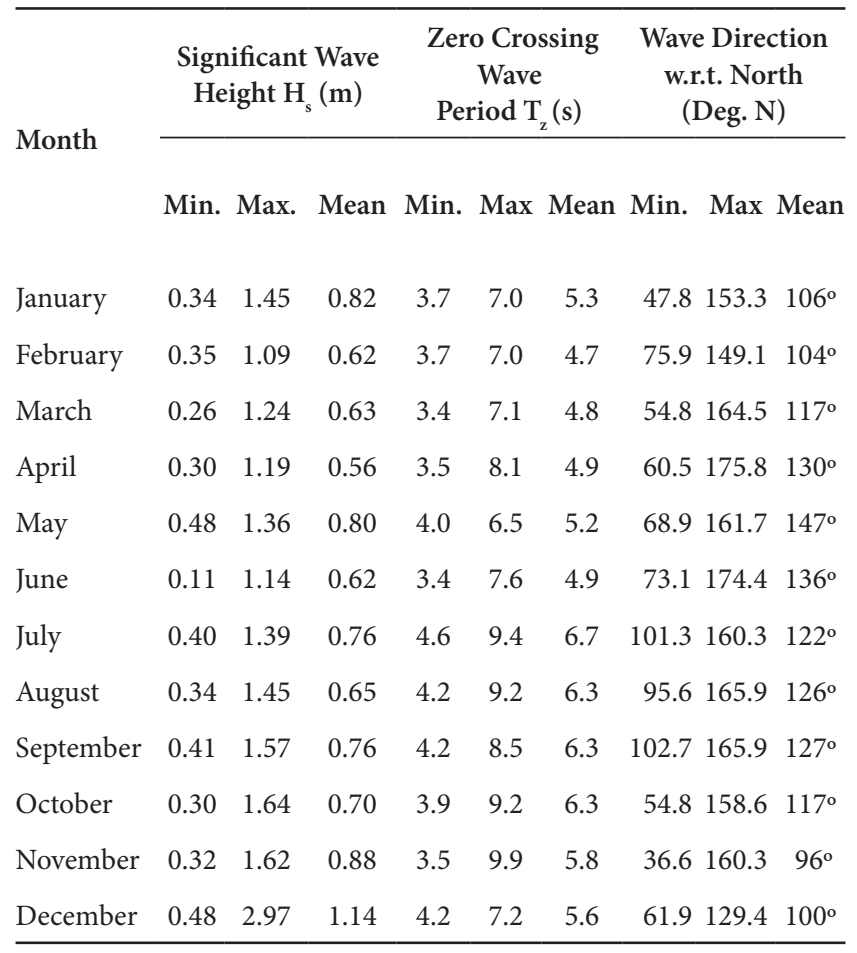

from 1998 to 2007 over the Grid No. 31816 represented by middle point at Latitude: $11.875^{\circ} \mathrm{N}$ and Longitude: $81.250^{\circ} \mathrm{E}$ were compiled from the GROW data base. The hind-cast wave characteristics for the period of one year i.e. from Janaury 2008 to December 2008 in deep water have been presented in the form of annual wave rose diagram are shown in Figure 2. The hind-cast wave characteristics at deep water depth is observed that wave height is vary between $0.21 \mathrm{~m}$ and $3.69 \mathrm{~m}$, the peak wave period is vary between $2.1 \mathrm{sec}$ and $19.9 \mathrm{sec}$ and the wave direction is vary between $9.3^{\circ}$ and $321.7^{\circ}$ w.r.t. North. It is seen that the directions of sea waves in the hind-cast wave data set were varying between $9.3^{\circ} \mathrm{N}$ and $321.7^{\circ}$ w.r.t. North. As the directions of waves near the Puducherry coast are likely to be between $25^{\circ} \mathrm{N}$ and $185^{\circ}$ w.r.t. North i.e coastal orientation of Puducherry coast is $105^{\circ}$ w.r.t. North, only sea waves in deep water having their propagation directions within the range, $25^{\circ} \mathrm{N} \leq \theta \leq 185^{\circ}$ w.r.t. North, are transformed to $15 \mathrm{~m}$ water depth.

In hind-cast data set, $76 \%$ of the time, sea waves were observed to have their propagation direction between $25^{\circ} \mathrm{N}$ and $185^{\circ}$ w.r.t. North. In the remaining $24 \%$ of the time, instead of sea waves the swells propagating towards the coast were transformed to $15 \mathrm{~m}$ depth, since the sea 


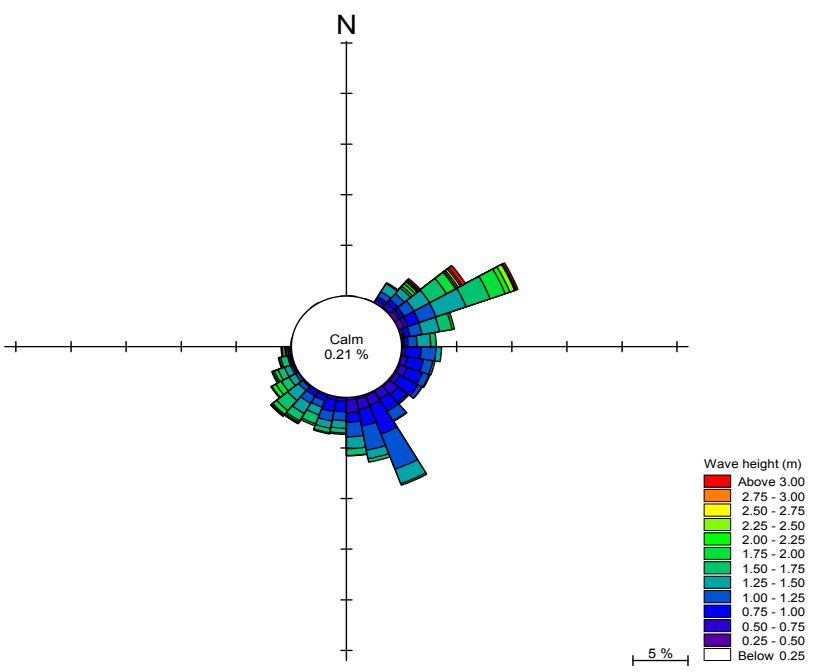

Figure 2. Annual rose diagram for hind-cast wave in deep water.

waves propagating in other directions will not reach the coast. Among these swell waves, only half of them have their directions between, $25^{\circ} \mathrm{N}$ and $185^{\circ}$ w.r.t. North; the remaining swell waves were propagating away from the coast, and they are replaced by swells with a minimum wave height of $0.25 \mathrm{~m}$ propagating perpendicular to the coast (i.e. $105^{\circ}$ w.r.t. North), since swell waves will always be present near the coast ${ }^{10}$.

\section{Comparison of Hind-Cast Wave With Measrued Wave Data}

To enable comparison of hind-cast wave parameters ${ }^{1}$ with the measured data in $15 \mathrm{~m}$ water depth, the hind-cast data in deep water are transformed to $15 \mathrm{~m}$ water depth. While transforming the hind-cast wave parameters, linear wave theory and Snell's law are used and the seabed contours are assumed straight and parallel in the nearshore region ${ }^{2}$. After wave transformation, the following data analyses viz., a) Correlation analysis, b) Comparison of annual wave rose plot, and c) scatter analysis of wave data are carried out for the comparison of measured and hind-cast wave data at $15 \mathrm{~m}$ water depth.

\subsection{Correlation Analysis}

For a quantitative comparison, the correlation analysis ${ }^{8}$ are carried out between the hind-cast data and the measured wave parameters which is defined as follows:

$$
C_{X}=\frac{\sum\left(X_{m}-\bar{X}_{m}\right)\left(X_{h}-\bar{X}_{h}\right)}{\sqrt{\sum\left(X_{m}-\bar{X}_{m}\right)^{2} \sum\left(X_{h}-\bar{X}_{h}\right)^{2}}}
$$

where, the cross-covariance coefficient, $C_{X}, N$ is the number of data points, and $\bar{X}_{m} \& \bar{X}_{h}$ are the mean values of the respective variables.

For a best fit between the hind-cast data and the measured data, $C_{x}$ should be unity ${ }^{5}$. The cross covariance coefficient between the hind-cast and measured wave parameters at $15 \mathrm{~m}$ water depth are presented in Table 2. It can be seen that wave height and wave direction, and the cross-covariance are high between the measured and the hind-cast wave parameters. But for wave period, crosscovariance coefficient is significantly low. This shows that the hind-cast values of wave height and wave direction agree better than the hind-cast wave period, with the measured data.

\subsection{Comparison of Annual Wave Rrose Plot}

For the comparison of both hind-cast and measured data at $15 \mathrm{~m}$ water depth, the annual wave height roses are plotted using DHI-MIKE21 module suite developed by Danish Hydraulic Institute (DHI), Denmark ${ }^{4}$. The annual wave height roses for the both measured and hind-cast wave data at $15 \mathrm{~m}$ water depth is shown in Figure 3. In the absence of zero crossing wave periods in the hind-cast wave data, the peak wave periods were used to compare the both measured and hind-cast wave data. The comparison of annual wave rose plot for wave period for the both measured and hind-cast wave data at $15 \mathrm{~m}$ water depth is shown in Figure 4.

From the annual plot of wave height roses (Figure 3), it is observed that the characteristics of hind-cast waves have close agreement with those of measured wave data. The wave roses at $15 \mathrm{~m}$ water depth which is transformed

Table 2. Cross covariance coefficient between the hind-cast and measured wave parameters in $15 \mathrm{~m}$ depth water

\begin{tabular}{lc}
\hline Wave parameters & Cross-covariance coefficient \\
\hline $\begin{array}{l}\text { Measured wave height Vs } \\
\text { Hind-cast wave height }\end{array}$ & 0.71 \\
$\begin{array}{l}\text { Measured wave direction Vs } \\
\text { Hind-cast wave direction }\end{array}$ & 0.68 \\
$\begin{array}{l}\text { Measured wave period Vs } \\
\text { Hind-cast wave period }\end{array}$ & 0.30 \\
\hline
\end{tabular}




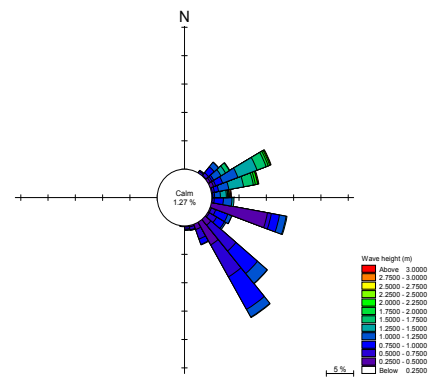

Hind-cast wave at $15 \mathrm{~m}$ water depth

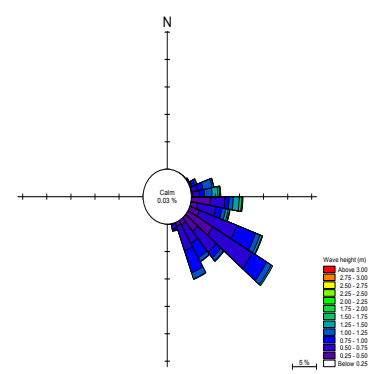

Measured wave at $15 \mathrm{~m}$ water depth
Figure 3. Comparison of annual rose diagram for wave height between hind-cast and measured wave data.

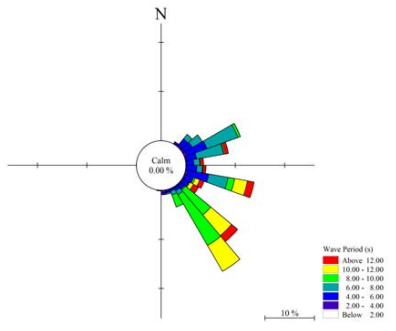

Hind-cast wave at $15 \mathrm{~m}$ water depth

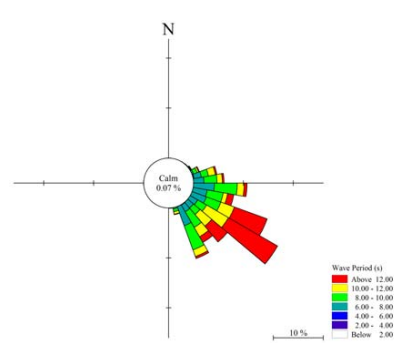

Measured wave at $15 \mathrm{~m}$ water depth
Figure 4. Comparison of annual rose diagram for peak wave period between hind-cast and measured wave data.

from hind-cast deep water waves compares well for the fair-weather period i.e months of February to April. During the monsoon seasons when the frequent occurrences of cyclones and storms ${ }^{7}$, the hind-cast wave transformed at $15 \mathrm{~m}$ water depth shows that waves were approaching from $30^{\circ} \mathrm{N}$ to $180^{\circ}$ w.r.t. North with predominantly waves coming from northeast direction $\left(60^{\circ} \mathrm{N}\right.$ to $150^{\circ}$ w.r.t. North) with the maximum wave height in the range of
0.5 to $2.0 \mathrm{~m}$. Where as measured wave rose at $15 \mathrm{~m}$ water depth shows that waves where approaching from $60^{\circ} \mathrm{N}$ to $180^{\circ}$ w.r.t. North with predominantly waves coming from southeast direction $\left(90^{\circ} \mathrm{N}\right.$ to $150^{\circ}$ w.r.t. North) with maximum wave height in the range of 0.5 to $1.5 \mathrm{~m}$. From the wave period roses (Figure 4), it is observed that the hindcast peak wave periods are vary from $4 \mathrm{~s}$ to $12 \mathrm{~s}$ where as the measured peak wave periods are vary from $6 \mathrm{~s}$ to $12 \mathrm{~s}$. It shows that the hind-cast wave peak wave period poor agreement with measured peak wave period.

\subsection{Scatter Analysis of Wave Data}

The scatter analysis of wave data for the both the measured and hind-cast wave at $15 \mathrm{~m}$ depth are carried out using DHI-LITPACK software developed by Danish Hydraulic Institute (DHI), Denmark ${ }^{4}$. The joint distribution of wave height and wave direction for the both the measured and hind-cast wave at $15 \mathrm{~m}$ depth are presented in Table 3 and Table 4 respectively. The joint distribution of wave period and wave direction for the both the measured and hindcast wave at $15 \mathrm{~m}$ depth are presented in Table 5 and Table 6 respectively. From the Table 3 and Table 4, it is observed that in the case of hind-cast wave, $33 \%$ of the time wave approaching angle is less than $90^{\circ} \mathrm{N}$ where as measured wave it is $12 \%$ of the time. In case of hind-cast wave data, the number of event with wave height more than $1 \mathrm{~m}$ is around $976(33.4 \%)$ whereas in case of measured wave, it is around $500(17 \%)$ i.e. nearly half. From the Table 5 and Table 6, it is observed that in the case of hind-cast wave, the $7 \%$ of waves with peak wave period more than $12 \mathrm{~s}$ where as $27 \%$ of wave with peak wave period more than $12 \mathrm{~s}$. It shows that the hind-cast wave peak wave period poor agreement with measured peak wave period.

Table 3. Joint distribution of wave height and wave direction - hind-cast wave at $15 \mathrm{~m}$ water depth

\begin{tabular}{|c|c|c|c|c|c|c|c|c|c|}
\hline \multirow{2}{*}{$\begin{array}{l}\text { Mean Wave } \\
\text { Direction (deg. N) }\end{array}$} & \multicolumn{9}{|c|}{ Hind-Cast Significant Wave Height $\left(\mathrm{H}_{\mathrm{s}}\right)(\mathrm{m})$} \\
\hline & $<0.5$ & $0.5-1$ & $1-1.5$ & $1.5-2$ & $2-2.5$ & $2.5-3.0$ & $3.0-3.5$ & $3.5-4.0$ & Row $\operatorname{Sum}(\theta)$ \\
\hline$<30$ & 0 & 0 & 0 & 0 & 0 & 0 & 0 & 0 & 0 \\
\hline $30-60$ & 18 & 94 & 106 & 27 & 0 & 0 & 0 & 0 & 245 \\
\hline $60-90$ & 33 & 97 & 395 & 136 & 31 & 19 & 4 & 0 & 715 \\
\hline $90-120$ & 314 & 219 & 121 & 0 & 0 & 0 & 0 & 0 & 654 \\
\hline $120-50$ & 204 & 801 & 127 & 0 & 0 & 0 & 0 & 0 & 1132 \\
\hline $150-180$ & 49 & 111 & 10 & 0 & 0 & 0 & 0 & 0 & 170 \\
\hline $180-210$ & 0 & 4 & 0 & 0 & 0 & 0 & 0 & 0 & 4 \\
\hline Sum Hs & 618 & 1326 & 759 & 163 & 31 & 19 & 4 & 0 & 2920 \\
\hline
\end{tabular}


Table 4. Joint distribution of wave height and wave direction - measured wave data at $15 \mathrm{~m}$ water depth

\begin{tabular}{lrrrrrrrrr}
\hline Mean Wave & \multicolumn{8}{c}{ Measured Significant Wave Height, $\mathrm{H}_{\mathrm{s}}(\mathrm{m})$} \\
\cline { 2 - 9 } Direction (deg. N) & $<0.5$ & $\mathbf{0 . 5 - 1}$ & $\mathbf{1 - 1 . 5}$ & $\mathbf{1 . 5 - 2}$ & $\mathbf{2 - 2 . 5}$ & $\mathbf{2 . 5 - 3 . 0}$ & $\mathbf{3 . 0 - 3 . 5}$ & $\mathbf{3 . 5 - 4 . 0}$ & Row Sum $(\theta)$ \\
\hline$<30$ & 0 & 0 & 0 & 0 & 0 & 0 & 0 & 0 & 0 \\
$30-60$ & 0 & 7 & 6 & 0 & 0 & 0 & 0 & 0 & 13 \\
$60-90$ & 18 & 165 & 162 & 13 & 5 & 1 & 0 & 0 & 364 \\
$90-120$ & 222 & 618 & 141 & 30 & 4 & 5 & 0 & 0 & 1020 \\
$120-150$ & 296 & 766 & 91 & 1 & 0 & 0 & 0 & 0 & 1154 \\
$150-180$ & 28 & 300 & 41 & 0 & 0 & 0 & 0 & 0 & 369 \\
$180-210$ & 0 & 0 & 0 & 0 & 0 & 0 & 0 & 0 & 0 \\
Sum Hs & 564 & 1856 & 441 & 44 & 9 & 6 & 0 & 0 & 2920 \\
\hline
\end{tabular}

Table 5. Joint distribution of peak wave period and wave direction - hind-cast wave at $15 \mathrm{~m}$ water depth

\begin{tabular}{lrrrrrrrr}
\hline $\begin{array}{l}\text { Mean Wave } \\
\begin{array}{l}\text { Direction } \\
\text { (deg. N) }\end{array}\end{array}$ & \multicolumn{6}{c}{ Hind-Cast Peak Wave Period, $\mathrm{T}_{\mathrm{p}}(\mathrm{m})$} \\
\cline { 2 - 9 } & $2-4$ & $4-6$ & $6-8$ & $8-10$ & $10-12$ & $>12$ & $\begin{array}{c}\text { Row } \\
\text { Sum }(\theta)\end{array}$ \\
\hline$<30$ & 0 & 0 & 0 & 0 & 0 & 0 & 0 & 0 \\
$30-60$ & 0 & 28 & 113 & 104 & 0 & 0 & 0 & 245 \\
$60-90$ & 0 & 30 & 226 & 392 & 18 & 9 & 40 & 715 \\
$90-120$ & 0 & 24 & 238 & 149 & 52 & 108 & 83 & 654 \\
$120-150$ & 0 & 22 & 83 & 36 & 548 & 362 & 81 & 1132 \\
$150-180$ & 0 & 26 & 33 & 34 & 77 & 0 & 0 & 170 \\
$180-210$ & 0 & 3 & 1 & 0 & 0 & 0 & 0 & 4 \\
Sum $\mathrm{T}_{\mathrm{p}}$ & 0 & 133 & 694 & 715 & 695 & 479 & 204 & 2920 \\
\hline
\end{tabular}

Table 6. Joint distribution of peak wave period and wave direction - measured wave at $15 \mathrm{~m}$ water depth

\begin{tabular}{lrrrrrrrr}
\hline $\begin{array}{l}\text { Mean Wave } \\
\begin{array}{l}\text { Direction } \\
\text { (deg. N) }\end{array}\end{array}$ & \multicolumn{6}{c}{ Measured Peak Wave Period, $\mathrm{T}_{\mathrm{p}}(\mathrm{m})$} \\
\cline { 2 - 9 } & $<2-4$ & $4-6$ & $\mathbf{6 - 8}$ & $\mathbf{8 - 1 0}$ & $\mathbf{1 0 - 1 2}$ & $>12$ & $\begin{array}{c}\text { Row } \\
\text { Sum }(\boldsymbol{\theta})\end{array}$ \\
\hline$<30$ & 0 & 0 & 0 & 0 & 0 & 0 & 0 & 0 \\
$30-60$ & 0 & 0 & 0 & 3 & 5 & 1 & 4 & 13 \\
$60-90$ & 0 & 1 & 5 & 113 & 140 & 81 & 24 & 364 \\
$90-120$ & 1 & 0 & 0 & 297 & 313 & 150 & 259 & 1020 \\
$120-150$ & 1 & 0 & 3 & 140 & 217 & 300 & 493 & 1154 \\
$150-180$ & 0 & 0 & 1 & 126 & 170 & 56 & 16 & 369 \\
$180-210$ & 0 & 0 & 0 & 0 & 0 & 0 & 0 & 0 \\
Sum $\mathrm{T}_{\mathrm{p}}$ & 2 & 1 & 9 & 679 & 845 & 588 & 796 & 2920 \\
\hline
\end{tabular}

\section{Discussion and Conclusion}

The hind-cast wave roses at $15 \mathrm{~m}$ depth compares well with measured waves for the fair-weather period i.e months of February to April. The vulnerability of Puducherry coast is high during the monsoon seasons ${ }^{7}$ when the frequent occurrences of cyclones and storms, the hind-cast wave data are not compares well with measured waves for the southwest monsoon period i.e. months of June to September and for the northeast monsoon period i.e. October to January. Further, a detailed analysis of measured and hind-cast wave data have to be carried out for the different stretch of coastal region. Hence, the preliminary study on waves \& report preparation and rough estimation of sediment budge one can use the hind-cast wave data. It is therefore prudent to perform a sensitivity analysis to handle the hind-cast wave data with the background knowledge on wave dynamics.

The problems dealing with long term coastline changes and planning mitigation measures to protect the coastline adversely affected by human interference, particularly along the East Coat of India where the littoral transport rate is generally high ${ }^{9}$, the prediction of sediment transport rates along the coast becomes very important. The changes in the basic data on wave height, wave period and wave direction which will significantly influence in the estimation of littoral drift along the coast ${ }^{9}$. It is however suggested to use the measured wave data for the estimation of sediment transport in order to arrive at more dependable values on littoral drift. 


\section{Acknowledgement}

Corresponding author express his sincere thanks to Dr. P. Chandramohan, Managing Director, Indomer Coastal Hydraulics (P) Ltd., Chennai, for supporting data for completion of this work.

\section{References}

1. Bender LC, Guinasso NL, Walpert JN, Howden SD. A comparison of methods for determining significant wave heights-applied to a 3-m discus buoy during hurricane Katrina. J Atmosph Ocean Technol-Jatmos Ocean Technol. 2010; 27:1012-28.

2. CERC Shore Protection Manual. I to III, 105. US Army Corps of Engineers, Coastal Engineering Research centre, US Govt. Printing Office, Coastal and Ocean Division, WW 4: 1984.

3. Cox AT, Cardone VJ, Swail VR. Early period reanalysis of ocean winds and waves. 8th International Wind and Wave Workshop; Oahu, Hawaii.

4. Danish Hydraulic Institute (DHI); An integrated modelling system for littoral process and coastline kinetics. Shore
Introduction and Tutorial. DHI Software; Copenhagen: 2010.

5. Hope ME, Westerink JJ, Kennedy AB, Kerr PC, Dietrich JC, Dawson $\mathrm{C}$, et al. Hind-cast and validation of Hurricane Ike (2008) waves, forerunner and storm surge. J Geophys Res C Oceans. 2013; 118:1-37.

6. Jena BK, Chandramohan P, Sanil Kumar V. Longshore transport based on directional waves along north Tamilnadu coast, India. J Coast Res. 2001; 17(2, Spring, 2001): 322-7.

7. Mani Murali R, Ankita M, Amrita S, Vethamony P. Coastal vulnerability assessment of Puducherry coast, India, using the analytical hierarchical process. Natur Hazards Earth Syst Sci. , 2013; 13:3291-311.

8. Remya PG, Raj Kumar, Basu S, Sarkar A. Wave hind-cast experiments in the Indian ocean using MIKE21 SW model. Indian Acad of Sciences. J Earth Syst Sci. 2012; 121(2): 385-92.

9. Sanil Kumar V, Pathak KC, Pednekar P, Raju NSN, Gowthaman R. Coastal processes along the Indian coastline. J Curr Sci. 2006; 91(4):530-36.

10. Sannasiraj SA, Goldstein MG. Optimal interpolation of buoy data into a deterministic wind-wave model. Nat Hazards. 2009; 49:261-74. 